Catherine Populaire MD, Serge Robard MD, Rémy Souron MD

\title{
An armoured endotracheal tube obstruction in a child
}

The case of a child whose tracheal tube became obstructed intraoperatively 30 minutes after intubation is reported. It appears that this obstruction was related to the development of bubbles within the walls which expanded upon exposure to nitrous oxide and diffusion of that gas into the bubbles. The authors want to point out the risk of gas diffusion into the walls of the tube and the possibility that repeated sterilization may enhance the development of bubbles.

Tracheal tube obstruction is a known complication of intubation with armoured tubes. We describe an unusual cause of obstruction that could have been avoided.

\section{Case report}

A healthy seven-month-old, $8 \mathrm{~kg}$ male presented for repair of a cleft lip and palate. He was premedicated with flunitrazepam $0.5 \mathrm{mg}$ and atropine $0.5 \mathrm{mg}$ per rectum. After induction of anaesthesia with halothane in $\mathrm{O}_{2}$ and $\mathrm{N}_{2} \mathrm{O}$, an intravenous line was inserted and thiopentone, dextromoramide and pancuronium were administered. Three minutes later the trachea was intubated with a disposable armoured polyvinyl orotracheal tube (size 3.5 mm Rusch). An oropharyngeal pack was also inserted. During the following thirty minutes, while the child was being photographed, $\mathrm{x}$-rayed and positioned, the lungs were ventilated with $\mathrm{N}_{2} \mathrm{O}$ and $\mathrm{O}_{2}$ without difficulty. After the surgeon inserted the mouth gag, peak inspiratory pressures increased from 22 to $30 \mathrm{~cm} \mathrm{H}_{2} \mathrm{O}$, breath sounds diminished and the expired tidal volume decreased. We continued to experience increasing difficulty in ventilating the lungs even after removal of the mouth gag. An attempt to pass a suction catheter through the tracheal tube failed so we extubated the patient and re-intubated him

\section{Key words}

ANAESTHESIA: paediatric; EQUIPMENT: tubes

endotracheal, complications, sterilisation.

From Département d'Anesthésiologie, Hôtel-Dieu, 44035 Nantes Cédex 01 - France.

Address correspondence to: $\mathrm{Dr} \mathrm{C}$. Populaire. with a new tracheal tube. Immediately we were able to ventilate the lungs again without difficulty. The ventilatory variables returned to their initial values and the surgical procedure was completed uneventfully. On inspection of the first tracheal tube, we noticed an intraluminal obstruction. Several cross-sections of the tube revealed that the polyvinyl wall was no longer adherent to the metallic rings (Figure). We examined several other similar tracheal tubes that had been re-sterilized and found the same defects.

\section{Discussion}

Airway obstruction with armoured tracheal tubes has been described previously. The problems encountered have related mostly to difficulties with the cuff or the inflating tube. Balloon herniation over the distal orifice of the tube or inside the tube at the cuff site has also been described. ${ }^{1-2}$ Eccentric cuff inflation resulting in the distal end abutting against the wall of the trachea has caused airway obstruction. ${ }^{3}$ In addition, dilatation of the balloon inflating tube at the proximal end of the tracheal tube has been reported. ${ }^{4}$ Obstruction of armoured latex tracheal tubes due to absorption of $\mathrm{N}_{2} \mathrm{O}$ into air bubbles within the tube wall has been described. ${ }^{5-6}$ The air bubbles, included in the wall during manufacture, expand after autoclaving and exposure to $\mathrm{N}_{2} \mathrm{O}$ and deflate after

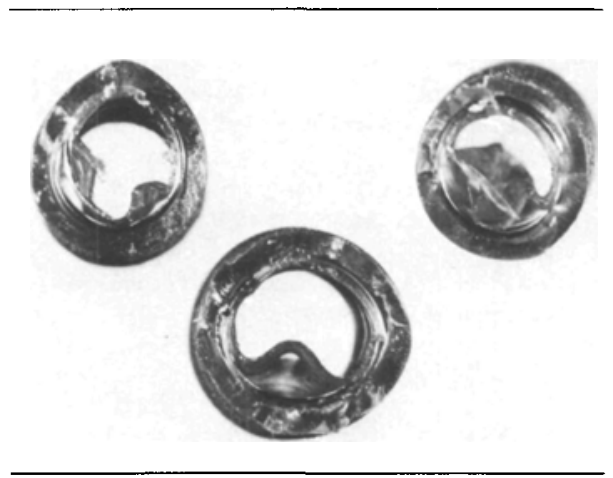

FIGURE Cross-sections of the endotracheal tube. 
elimination of $\mathrm{N}_{2} \mathrm{O} .^{6}$ This recognized complication in adults is more likely to be devastating in a child because of the smaller internal diameter of the tubes.

In maxillo-facial surgery we prefer to use armoured tracheal tubes. We stopped using armoured latex tubes several years ago, because their wall thickness resulted in a large outside diameter and a relatively small inside diameter. For the past five years we have been using armoured polyvinyl tracheal tubes ("RUSCHELIT"). We have been re-using each tube several times and sterilizing them by autoclaving.

In the case described, dissection of the tracheal tube is probably due to two factors. Re-sterilization by autoclaving resulted in the formation of bubbles between the individual layers. The manufacturers recommend that the tubes should be used only once. Storage of the tracheal tubes close to a warm source (the autoclave) may have been an additional factor. Occlusion of the tube 30 minutes after intubation is probably secondary to the progressive expansion of the bubbles by the diffusion of $\mathrm{N}_{2} \mathrm{O}$. Although we had changed to 100 per cent $\mathrm{O}_{2}$ before extubating the child we did not notice any reduction in the degree of obstruction. Presumably, the time allowed for $\mathrm{N}_{2} \mathrm{O}$ to rediffuse was too short. Examination of other re-sterilized, polyvinyl armoured tubes showed this apparent dissection of the internal wall at different levels, but without complete intraluminal occlusion.

In conclusion, this complication should not be encountered again as we now use these armoured tracheal tubes only once.

\section{References}

1 Famewo $C E$. A not so apparent cause of intraluminal tracheal tube obstruction. Anesthesiology 1983; 58: 593.

2 Robbie DS, Pearce DJ. Some dangers of armoured tubes. Anaesthesia 1959; 14: 379-85.

3 Mirakhur RK. Airway obstruction with cuffed armoured tracheal tubes. Can Anaesth Soc J 1974; 21: 251-3.

4 Abramowitz MD, McNabb TG. A new complication of flexometallic endotracheal tubes. Br J Anaesth 1976; 48: 928.

5 Munson ES, Stevens DS, Redfern RE. Endotracheal tube obstruction by nitrous oxide. Anesthesiology 1980; 52: 275-6.

6 Ohn $K C, W u W H$. Another complication of armoured endotracheal tubes. Anesth Analg 1980; 59: 215-6.

\section{Résumé}

Les auteurs rapportent l'observation d'un enfant de sept mois dont la sonde trachéale s'est obstruée 30 minutes après l'intubation. Cette obstruction était due à l' expansion de bulles incluses dans la paroi du tube après exposition au $\mathrm{N}_{2} \mathrm{O}$ et diffusion de celui-ci à l'intérieur des bulles. Ils accusent également la stérilisation répétée de la sonde armée (contre l'avis du constructeur) d'avoir favorisé le dèveloppement de ces inclusions bulleuses. 